Article

\title{
Student's Satisfaction of the Quality of Online Learning in Higher Education: An Empirical Study
}

\author{
Carmen Jiménez-Bucarey ${ }^{1}{ }^{(\mathbb{C}}$, Ángel Acevedo-Duque ${ }^{2, *} \mathbb{C}$, Sheyla Müller-Pérez ${ }^{3}{ }^{\circledR}$, Luis Aguilar-Gallardo ${ }^{1}$, \\ Miguel Mora-Moscoso ${ }^{1}$ and Elena Cachicatari Vargas ${ }^{4}\left[{ }^{\mathbb{C}}\right.$ \\ 1 Vice-Rectorate of Quality Assurance, Universidad Andrés Bello, Santiago 7550000, Chile; \\ carmen.jimenez@unab.cl (C.J.-B.); luis.aguilar@unab.cl (L.A.-G.); miguel.mora@unab.cl (M.M.-M.) \\ 2 Public Policy Observatory Faculty of Business and Administration, Universidad Autónoma de Chile, \\ Santiago 7500912, Chile \\ 3 Faculty of Economics and Busines, Universidad San Sebastián, Bellavista 7, Santiago 8420524, Chile; \\ smullerp@docente.uss.cl \\ 4 Faculty of Health Sciences, Universidad Nacional Jorge Basadre Grohmann, Tacna 23000, Peru; \\ ecachicatariv@unjbg.edu.pe \\ * Correspondence: angel.acevedo@uautonoma.cl
}

check for updates

Citation: Jiménez-Bucarey, C.; Acevedo-Duque, Á.; Müller-Pérez, S.; Aguilar-Gallardo, L.; Mora-Moscoso, M.; Vargas, E.C. Student's Satisfaction of the Quality of Online Learning in Higher Education: An Empirical Study. Sustainability 2021, 13, 11960. https://doi.org/10.3390/su132111960

\section{Academic Editors:}

Carlos Hervás-Gómez, María

Dolores Díaz-Noguera,

Pedro Román-Graván and María de los Ángeles Domínguez-González

Received: 7 September 2021

Accepted: 22 October 2021

Published: 29 October 2021

Publisher's Note: MDPI stays neutral with regard to jurisdictional claims in published maps and institutional affiliations.

Copyright: (c) 2021 by the authors. Licensee MDPI, Basel, Switzerland. This article is an open access article distributed under the terms and conditions of the Creative Commons Attribution (CC BY) license (https:/ / creativecommons.org/licenses/by/ $4.0 /)$.

\begin{abstract}
Higher education institutions (HEIs) have been facing a digital transformation in online learning as a result of the restrictions generated by COVID-19. Therefore, identifying which are the elements that influence student satisfaction will allow HEIs to establish strategies to ensure the quality of the digital transformation. This study proposes a model that measures student satisfaction considering three dimensions: teacher quality, technical service quality and service quality. Then, the impact of each dimension on student satisfaction is estimated using a Partial Least Squares Structural Equation Model (PLS-SEM), and finally an Importance-Performance Map Analysis (IPMA) was performed to identify the improvements that should be made to increase student satisfaction. When analyzing the responses of 1430 students at the School of Medicine, it was found that the quality of technical service should be improved, specifically training, and encouraging teachers to use strategies that allow student participation.
\end{abstract}

Keywords: IPMA; digital transformation in education; student satisfaction; distance higher education; online learning

\section{Introduction}

The emergence of the health emergency generated by COVID-19 in the university teaching game scenario has posed an unprecedented challenge at the political, administrative and pedagogical levels of nations [1]. Universities, like other educational institutions, have been forced to continue teaching telematically and ensure its quality as much as possible. This effort is circumscribed to a pandemic with catastrophic consequences, in which social gaps, connectivity, family reconciliation and other problems that already dragged the "old normal" hit harder at this time.

This situation is explained by elements such as: the impact of the globalization of markets [2,3], the international trend towards a more heterogeneous and inclusive student population with diversity and inclusion in their spaces [4,5], higher levels of demand for quality control and satisfaction [6,7], the emergence and rapid diffusion of information and communication technologies in university settings [8,9], the increase of student mobility to quality education exporting countries $[10,11]$, the formation of academic consortia [12,13], and the increasing levels of diversification and privatization of higher education systems [14,15].

Therefore, university organizations must generate a prospective that facilitates the creation of shared actions with their students, directing their efforts towards the search 
for efficiency, with the commitment to contribute to the management of cooperation and teaching-learning networks with a vision of quality [3].

Training experts agree that competency certification models, such as the IPMA model, constitute a clear bridge between competency-based training and employability. The new context offers opportunities for professional competencies to be inserted in the training processes, to achieve an adaptation to the needs of comprehensive training (with values) and oriented to improve the employability of graduates [10]. Certification is considered as an instrument to link external agents from the different professional sectors to the training processes. However, for this linkage to be effective, it needs to be accompanied by changes in the learning processes [11].

In this sense, the current scope of educational objectives is achieved through the use of the educational technological platform provided by the university, in which teachers and students enter for the opening of the teaching-learning process from the virtuality approach, in addition to different communication platforms and thus making possible the realization of synchronous and asynchronous activities, where students and teachers make the effort for the maximum development of most of their competences [16].

The above could be impacting directly on the ease of access and daily use of recent information and communication technologies which has allowed an impressive development of fully virtual university offers [17]. These developments have also raised important questions about which determinants affect the quality of service, learning, performance, and retention of students in these academic offerings. One of these determinants is the degree to which virtual courses or programs meet student expectations, which is attributed to teacher quality, service quality, and technical quality of services.

For these reasons, the objective of this present empirical study is to determine which is the dimension and item that most influences in student's satisfaction, which allows improvements to be implemented in the online learning. We propose a theoretical model that allows first to determine the constructs that influence student satisfaction with respect to the online learning modality using a Partial Least Squares Structural Equation Model (PLS-SEM). The model in the present research seeks to investigate four hypotheses:

Hypothesis 1 (H1). Service quality (management) positively affects student satisfaction.

Hypothesis 2 (H2). Teacher quality positively affects student satisfaction.

Hypothesis 3 (H3). Technical quality positively affects student satisfaction.

Hypothesis 4 (H4). Technical quality positively affects teacher quality.

After the PLS-SEM estimation, an Importance-Performance Map Analysis (IPMA) is performed to identify possible areas for improvement at the construct and indicator levels. This study seeks to contribute to improve the quality of online learning currently offered by HEIs and the evaluation of students in the digital transformations that HEIs will continue to manage until the effects of COVID-19 are controlled.

\section{Background}

\subsection{Quality of Service in Online Learning}

(Hypothesis 1). Universities as a higher education center are those who govern the task of knowledge management and it is where the teaching-learning activities of all strategies and practical theoretical resources are developed for the purpose of training quality professionals, adding to the contribution of innovative and creative ideas that meet the needs of society, as well as the labor market $[18,19]$.

From these perspectives the quality of service from the online learning perspective is focused on the service provided by university institutions for the implementation of online classes by different actors [20]. This leads to the fact that the service management in the online channels of academic management such as applications, registrations, scheduling, 
among others, is considered as a key standard for the evaluation of the quality of virtual education [21], in that proper handling of responses to requirements such as student support services offered by the university is associated with student performance and retention in virtual courses, but the empirical evidence on this is still inconclusive [22].

Given the responsibility of universities to maintain an optimal and quality service and that their students have an excellent educational service, since online learning is attributed to good Internet access and adequate equipment for non-face-to-face classes [23], it has been found that student satisfaction is mediated by factors that are not directly associated with the course or the educational institution.

It is difficult to question the concept quality of the above in its application to educational services, an interesting example of this plurality of meanings was observed in the EFA (Education For All) Global Monitoring Report 2005, published by the Organization of National Units for Education, Science and Culture (UNESCO), subtitled: "The quality imperative" [24].

This report examined the way in which educational quality is conceived and expressed from the humanistic paradigm, the behaviorist paradigm and the critical paradigm. This method has been the foundation and tool of critical pedagogy, whose relevance in the current historical moment cannot be sufficiently emphasized by authors such as Laval [25] in France, Duhalde [26] in Argentina, Sander [27] in Brazil, and Flecha [28,29] in Spain, to mention some of the voices echoed in this presentation, have analyzed the intricate epistemological, political, ideological, economic and ethical fabric that is articulated in educational practice and its administration.

It is proposed that each approach will lead to observe different indicators to determine whether the quality of service in online learning and student satisfaction can be achieved efficiently, which must be present in the system and at all levels [30]. The above was established in a model of quality of results, quality of final product, which warns us, above all, of the fact that under these ideas often lie the concepts of the ideology of social efficiency that considers the teacher as little more than a line worker who uses instructional packages, whose objectives, activities and materials come prefabricated, and in which "quality" is measured by almost isolated phenomena, which are collected in the final product [31,32].

\subsection{Teacher Quality in Online Learning}

(Hypothesis 2). It is important the role of university teachers in these scenarios, and their performance in online teaching and learning processes, should be based on the integration and implementation of their competences in Information Technology and Communication (ICT), as well as the development of their quality as teachers in the strategies they currently use to face distance classes [33], being defined as competences with practical and knowledge skills that the same teacher develops through the strategies used in non-face-to-face classes which these allow the participation of students, recognizing as one of the most important the use of new technologies called digital competence [34].

The management of the strategies used by teachers for the evaluation of learning in non-face-to-face classes, these must be adequate since they are considered in the last decade as strategic resources for training and learning management [35]. In this regard, [36]. The above shows that the client with this type of competence is understood as the consequence of the integration of resources such as knowledge, skills and attitudes, among others, expressed in their work performed at work.

Meanwhile, Latin American countries such as Mexico, Brazil and Chile are the most outstanding for their higher education models [36-38], this is due to the management of didactic strategies used in non-presential classes which, perhaps, allow students to learn effectively. Although the first two countries seem to have greater influence in the rest of the continent, Chile is the first to reformulate the university system in the 1980s and orient it according to the policies of privatization and accreditation of educational quality. The new sociocultural scenario has promoted changes in the organization of universities, as 
well as in the training of their teachers, which brought new challenges to university study houses [39].

This transitory process makes it necessary to propose a critical review of university teaching [40]. The quality of university teaching is understood as an educational practice, i.e., a continuous training process composed of intentional and reflective actions, given within the relationship between the teacher and the student [41,42]. Through it, it is intended to fulfill the formative purposes with quality that enable students for the professional field of the labor and social world. It is, at the same time, a social practice, since teachers and their activity are immersed in a particular social, political and cultural context that will inevitably influence the way they develop their profession.

\subsection{Quality of Technical Service and Teacher Performance in Online Learning}

Hypothesis $\mathbf{5}$ (H5). Technical quality of the technical system positively affects student satisfaction.

Hypothesis 6 (H6). Technical quality of the educational system positively affects teacher quality.

Higher education is never independent of the social context in which it unfolds [43]. In the case of the Latin American region, where there is a strong presence of countries that are usually classified as emerging within the current framework of international development, it is necessary to take note of the transformations that they are experiencing, and that have an impact on education at different levels, and particularly on tertiary or higher education in online scenarios, especially when it focuses on quality management and its technical support platform to provide a timely and accurate response to students [44]

The above marks with much significance the opportunity response management for the resolution of the different inconvenience that students in their training as professionals, when these are presented in online class activities or non-face-to-face classes, where immediately interferes the technical supports of platform [45].

The notion of quality in the educational system for the management of technical support appears at this time of crisis as a central concept in many international studies for this moment, where the development of higher education shows an accelerated activity in the last 35 years and, as in the world, in Latin America it has been a topic of debate since it began to be part of public policy, gaining great influence in the construction of the higher education system in the region $[46,47]$.

Today the notion of educational quality is being widely used in public discourse, where to know quality indicators and addressing issues such as: the use of the platform for non-face-to-face classes, whether or not they have an adequate interface, non-face-to-face classes are regularly stable (no intermittency or connection failures), universities respond to doubts about the functioning of non-face-to-face learning platforms. This and other issues are currently handled with great concern by the governments of different nations worldwide and in Latin America, leading to sustainable quality service education [45].

Figure 1 shows the proposed theoretical model, showing the technical quality of the educational system positively affects teacher quality. It is clear that the current problem in Western countries is not so much in the universalization of education but in guaranteeing their citizens access to quality education $[39,46]$. Their main priority is not to grow quantitatively but to manage the quality of education correctly and facilitate access to all citizens to a more demanding education [22,43]. 


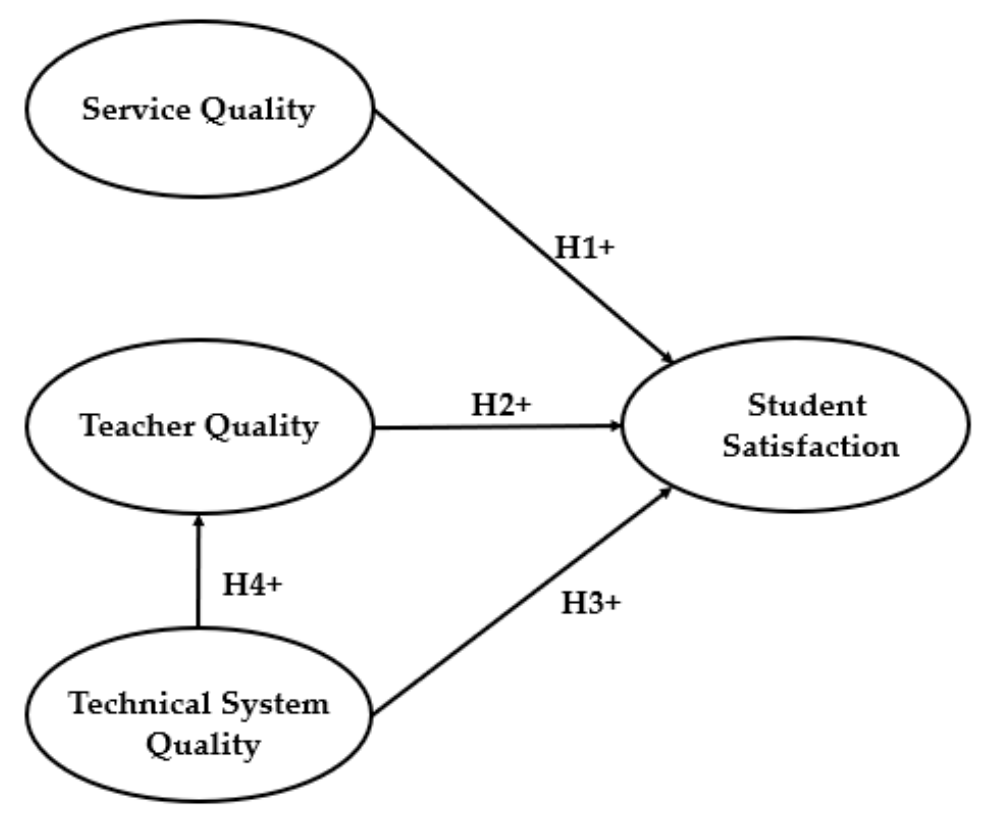

Figure 1. Proposed theoretical model. Source: own elaboration.

\section{Materials and Methods}

To measure student satisfaction as a result of the implementation of online learning, the university designed a reduced survey in September 2020. The survey considered 13 items or indicators that were answered through a Likert scale of four categories, one unfavorable and four favorable. These indicators form four dimensions or constructs: service quality, teacher quality, technical system quality and student satisfaction (Table 1). This survey was designed in conjunction with the various actors who were part of the implementation process of the distance classes, such as, for example, the directors of the different careers and experts in teaching methodologies.

Table 1. Survey.

Teacher Quality 
Since the implementation of online learning was a new experience for all HEIs, the development of studies that measure student satisfaction is still under discussion [45,48]. In order to define the survey constructs, the Multidimensional Conceptual Model for Evaluating E-learning System Success (ESSS model) was used [46], but online learning is not the same as e-learning. Therefore, the survey was designed and validated with the most relevant actors of the implementation process in online learning, such as: the directors of different career, experts in teaching methodologies and Vice-Rectorate of Quality Assurance.

The university invited all students $(45,000)$ by e-mail to respond to the survey on a voluntary basis. A total of 7380 students $(16.4 \%)$ responded to the invitation, but for this study we only had access to $1,430(3.1 \%)$ responses from students belonging to the School of Medicine. The sample is small in percentage terms, but one of the advantages of estimating PLS-SEM models is that it is not necessary to have a large sample to obtain robust results. According to the number of constructs and items, a minimum of 145 responses is required for the data to show a statistical power of $80 \%$ with a significance level of $1 \%$.

To test the hypotheses posed in the theoretical model, a Partial Least Squares Structural Equation Model (PLS-SEM) was used to predict which construct most impacts students' perception of teacher quality in online classes [49,50], and Importance-Performance Map Analysis (IPMA) to identify possible areas for improvement using. Software SmartPLS version 3.0 was used to estimate the PLS-SEM model and IPMA.

\subsection{Partial Least Squares SEM (PLS-SEM)}

According to Hair et al. [51], the PLS-SEM estimation process consists of two parts: evaluation of the reflective measurement model and evaluation of the structural model.

\subsubsection{Evaluation of the Reflective Measurement Model}

a. Internal Consistency Reliability: Cronbach's alpha $(\alpha)$ and consistency reliability (RC) is $\geq 0.70$.

b. Convergent Validity: Outer loading is $\geq 0.70$ and average variance extracted (AVE) is $\geq 0.50$.

c. Discriminant Validity: none of the construct combinations the Heterotrait-Monotrait Ratio (HTMT) must include the value of 1.

\subsubsection{Evaluation of the Structural Model}

(a) Coefficient of determination ( $\mathrm{R}^{2}$ adjusted): the following values represent predictive power of the model: 0.25 (weak), 0.50 (moderate) and 0.75 (significant).

(b) Magnitude and significance of the path coefficients: when $p$-value $\leq 0.05$, it is concluded that the path coefficients are significant, so that the hypothesis put forward in the study can be accepted.

(c) Predictive relevance $\left(\mathrm{Q}^{2}\right): \mathrm{Q}^{2}>0$ the model has predictive relevance,

(d) Effect size $\left(\mathrm{f}^{2}\right)$ : values of $0.02,0.15$ and 0.35 are considered small, moderate, and large effects of an exogenous construct on an endogenous construct.

(e) Effect size $\left(\mathrm{q}^{2}\right)$ : values of $0.02,0.15$ and 0.35 are considered small, moderate and large effects for the endogenous construct.

\subsection{Importance-Performance Map Analysis (IPMA)}

The IPMA allows the PLS-SEM results to be extended by comparing the path coefficients (importance) with the mean scores of each construct or indicator (performance). The IPMA is a tool that can be used to propose relevant improvements in the constructs and/or indicators that make up the model, identifying constructs and/or indicators that reflect relatively high importance and relatively low performance (Ringle and Sarstedt, 2016). In performance, the score of an observation $j$ with respect to each indicator $i$ is rescaled from 0 to 100 :

$$
\mathrm{x}_{\mathrm{ij}}^{\text {reescalado }}=\frac{\mathrm{E}\left[\mathrm{X}_{\mathrm{ij}}\right]-\min \left[\mathrm{x}_{\mathrm{i}}\right]}{\max \left[\mathrm{X}_{\mathrm{i}}\right]-\min \left[\mathrm{x}_{\mathrm{i}}\right]} * 100,
$$


Therefore, if all students answered three, the performance would be ((3 - 1)) / ((4 $-1) * 100=66$ ). The survey and the PLS-SEM model must meet following requirements: scale of the survey metric, the coding of all indicators has the same scale direction, the weights of the estimates have the same sign, and positive total effects (Hair et al., 2018).

\section{Results}

\subsection{PSL-SEM: Evaluation of the Reflective Measurement Model}

Table 2 shows that all the constructs of the proposed model meet the criteria of internal consistency, convergent and discriminant validation. Therefore, the final theoretical model would be the one shown in Figure 2.

Table 2. Evaluation results of the reflective measurement model.

\begin{tabular}{|c|c|c|c|c|c|c|}
\hline \multirow[b]{2}{*}{ Constructs } & \multirow[b]{2}{*}{ Item } & \multicolumn{2}{|c|}{ Internal Consistency Reliability } & \multicolumn{2}{|c|}{ Convergent Validity } & \multirow{2}{*}{$\begin{array}{c}\text { Discriminant Validity } \\
\text { Confidence Interval } \\
\text { HTMT Doesn't } \\
\text { Have } 1\end{array}$} \\
\hline & & $\begin{array}{c}\text { Cronbach's } \\
\text { Alpha } \alpha \geq 0.70\end{array}$ & $\begin{array}{l}\text { Composite } \\
\text { Reliability } \\
\text { (CR) } \geq 0.70\end{array}$ & $\begin{array}{l}\text { Outer Loading } \\
\quad \geq 0.70\end{array}$ & $\mathrm{AVE} \geq 0.50$ & \\
\hline $\begin{array}{l}\text { Teacher Quality } \\
\text { (TQ) }\end{array}$ & $\begin{array}{l}\text { TQ1 } \\
\text { TQ2 } \\
\text { TQ3 }\end{array}$ & 0.752 & 0.858 & $\begin{array}{c}0.78 \\
0.816 \\
0.855\end{array}$ & 0.668 & Yes \\
\hline $\begin{array}{l}\text { Service Quality } \\
\text { (SQ) }\end{array}$ & $\begin{array}{l}\text { SQ1 } \\
\text { SQ2 } \\
\text { SQ3 }\end{array}$ & 0.746 & 0.855 & $\begin{array}{l}0.828 \\
0.844 \\
0.771\end{array}$ & 0.664 & Yes \\
\hline $\begin{array}{c}\text { Technical } \\
\text { System Quality } \\
\text { (TSQ) }\end{array}$ & $\begin{array}{l}\text { TSQ1 } \\
\text { TSQ2 } \\
\text { TSQ3 } \\
\text { TSQ4 }\end{array}$ & 0.727 & 0.83 & $\begin{array}{l}0.731 \\
0.705 \\
0.741 \\
0.785\end{array}$ & 0.549 & Yes \\
\hline $\begin{array}{c}\text { Student } \\
\text { Satisfaction (SS) }\end{array}$ & $\begin{array}{l}\text { SS1 } \\
\text { SS2 } \\
\text { SS3 }\end{array}$ & 0.771 & 0.867 & $\begin{array}{l}0.836 \\
0.861 \\
0.786\end{array}$ & 0.686 & Yes \\
\hline
\end{tabular}

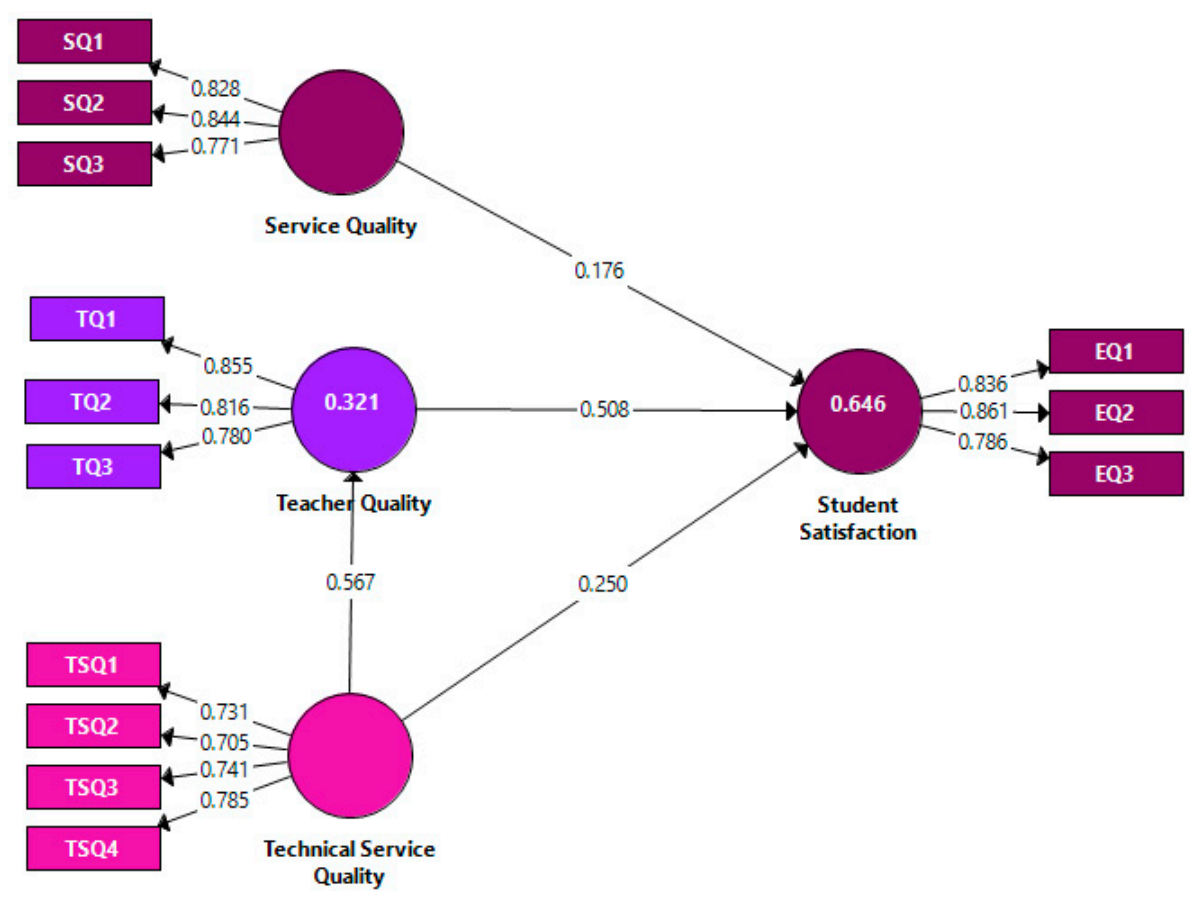

Figure 2. Results of the structural model. 
Table 3 shows the values of the Heterotrait-Monotrait Ratio (HTMT) confidence intervals, confirming that the model complies with the discriminant validation. The next step is to validate the structural model.

Table 3. Confidence Intervals.

\begin{tabular}{cccc}
\hline & HTMT Ratio & $\mathbf{5 . 0 0 \%}$ & $\mathbf{9 5 . 0 0 \%}$ \\
\hline SQ -> TQ & 0.647 & 0.599 & 0.695 \\
SS -> TQ & 0.965 & 0.939 & 0.991 \\
SS -> SQ & 0.79 & 0.749 & 0.831 \\
TSQ -> TQ & 0.76 & 0.714 & 0.806 \\
TSQ -> SQ & 0.968 & 0.938 & 0.997 \\
TSQ -> SS & 0.879 & 0.847 & 0.911 \\
\hline
\end{tabular}

\subsection{PSL-SEM: Evaluation of the Structural Model}

Table 4 shows the results of the path coefficients and p-values, the construct that most influences Student Satisfaction (SS) is the Teacher Quality (TQ) with a path of 0, and it can also be seen that the Technical System Quality (TSQ) has a high impact (0.567) on teacher quality. Therefore, all the hypotheses are accepted. The path only considers the direct effect of each construct on SS. However, considering the indirect effect of TSQ $\rightarrow \mathrm{TQ} \rightarrow \mathrm{SS}(0.288)$, TSQ has the greatest impact on SS (0.538).

Table 4. Structural model evaluation results.

\begin{tabular}{cccccc}
\hline Hypothesis & Path & Coefficients Path & T Statistics & $\boldsymbol{p}$-Value & Support \\
\hline H1 & TQ -> SS & 0.508 & 24.244 & 0 & Yes \\
H2 & TQ -> SS & 0.176 & 7.284 & 0 & Yes \\
H3 & TSQ -> SS & 0.250 & 10.249 & 0 & Yes \\
H4 & TSQ -> TQ & 0.567 & 26.314 & 0 & Yes \\
\hline
\end{tabular}

A moderate predictive power (adjusted $\mathrm{R}^{2}$ of 0.645 ) of the constructs Technical System Quality (TSQ), Teacher Quality (TQ), and Service Quality (SQ) on Student Satisfaction (SS) and a weak predictive power (0.321) of TSQ on TQ is observed. The model presents a predictive significance $\left(\mathrm{Q}^{2}\right)$ for SS (0.439) and TQ (0.212). A large size effect $\left(\mathrm{f}^{2}\right)$ is found for the TQ construct (0.485) on SS, a weak effect of SQ (0.042) and TSQ (0.076) on SS and a large effect of the TSQ construct (0.473) on ESQ.

As the proposed theoretical model satisfies the validation criteria, the next step is to estimate the IPMA by construct and items to identify possible areas for improvement.

\subsection{Importance-Performance Map Analysis (IPMA)}

\subsubsection{IPMA by Construct}

In Figure 3 we can compare the importance (horizontal axis) of each construct with its performance (vertical axis). It can be seen Technical System Quality (TSQ) is the most important construct in the model (0.538), but its performance is not (55.533). Therefore, if the university seeks to improve student satisfaction, priority should be given to improving the performance of the TSQ construct.

\subsubsection{IPMA by Items}

If the analysis is by items, in the Figure 4 shows that the Teacher Quality (TQ1 \& TQ2) indicators are the most important, but their performance is below average. Therefore, if the university seeks to improve the levels of student satisfaction, priority should be given to improving the TSQ indicators, specifically: (a) the strategies that my professors use in the online format classes allow student participation and (b) the didactic strategies used in the online format classes allow effective learning. 


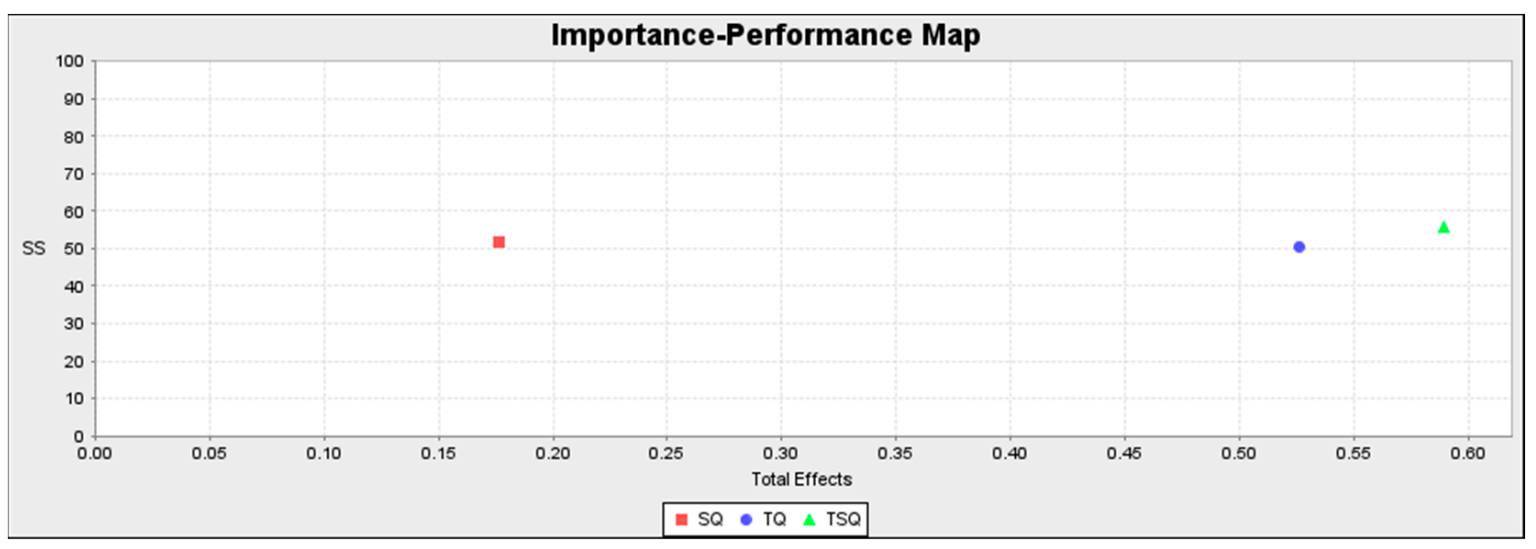

Figure 3. IPMA results by construct.

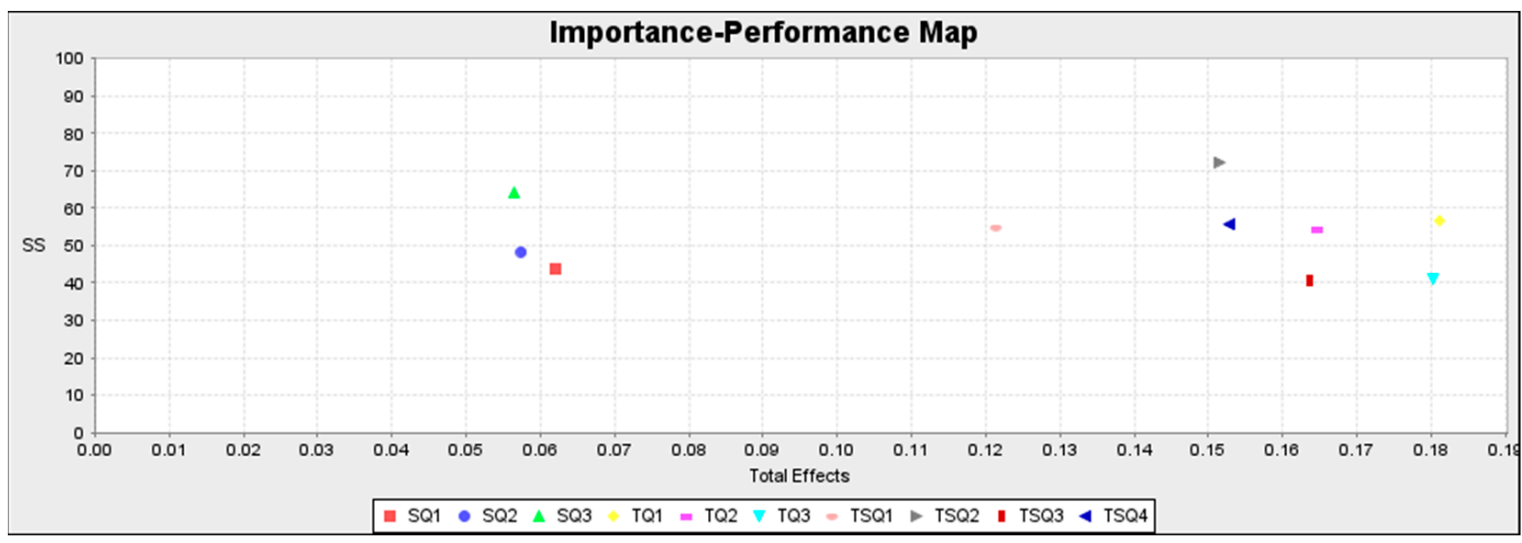

Figure 4. IPMA results by indicator.

When observing the results of the analysis by construct and items, results can be found that seem to be contradictory, but this is not the case, since TQS and TQ have a high importance ( 0.538 and 0.508 , respectively). Therefore, first we can consider the result obtained by the analysis by construct and then identify within this construct those items with high importance, but with low performance (TQS3 \& TQS4), but without forgetting the items that, although they are in another construct which can also have a high importance as it is in this case TQ1 and TQ2. In general, it would be recommended to improve TSQ3, TQ1 \& TQ2 performance.

\section{Discussion}

In the last three decades, the processes of quality assurance of the university education system have become a matter of interest worldwide, as well as a topic of great relevance within the countries that make up the Latin American and Caribbean horizon, with greater emphasis on the quality of online learning based on student satisfaction [52].

For the purposes of this research and in order to measure the satisfaction of medical students as a result of the implementation of online learning, the university designed a reduced survey in September 2020, these indicators form four dimensions or constructs: quality of service, quality of the teacher, quality of the technical system and student satisfaction (Table 1).

In this scenario for the authors Esteve-Faubel, RP; Oller-Benitez, A [53], it is possible to observe that, within the different countries that make up Latin America, these concerns have given way to a series of structures, associations and specialized units that have proposed as a goal the development of different efforts and strategies aimed at improving quality and maintaining it sustainable in the educational system, in this same sense relevant to Al-bornoz, Marcelo E. [54], points out the development of processes aimed at creating 
standardized criteria for the evaluation and accreditation of these units, with the intention of establishing the minimum standards required for their operation.

For each of them, quality requirements are established, given the results of this re investigation, the four hypotheses are accepted, being the TSQ the one that has the greatest impact on student satisfaction, the TSQ is the one that has the greatest positive effect on the SS, but it must be considered that the TSQ affects the TQ and indirectly positively affects the SS, it is evident at first that a series of quality tools are developed that are marked in the service, complementing each other in the processes, in the systems and in the teaching, showing the reality of higher education in Latin American universities, specifically in Chile, given that the events caused by globalization have produced changes in the management of quality and in their educational models as commented by the authors Gonzá-lez-Zamar, M.-D.; Abad-Segura, E.; López-Meneses, E.; Gómez-Galán, J. [55]. and Pulido Chaves, Orlando [56].

In this sense, Chau, P [57]. states that traditionally teaching practice was based on an educational model centered on teaching and the teacher, where the ultimate goal was the transmission of knowledge. This shows interesting information with respect to the present research where the results are analyzed by construct, the TSQ should be improved, since the IPMA shows that it is the most important, but there is still opportunity to improve its performance (valuation in the response), as well as when analyzing by indicator. It is observed that the teaching quality items have a high importance when estimating student satisfaction [58]. However, work should be done specifically in the training and incentivization of teachers to use strategies that allow student participation [59].

Authors such as Rojas, M.M., Moreno, G.A., and Rosero, C.A. [60] affirm that it is important to train teachers to continue with the digital transformation while maintaining quality standards and ensuring sustainable education for the duration of the pandemic. For its part, educational quality in Latin American scenarios, does not escape the closely related concepts, being a platform for continuous improvement for the higher education system [61].

If we speak of quality, it is because implicitly or explicitly an evaluation has been made and if it is evaluated, it is done with some criteria. In this sense: "it is hardly congruent to speak of quality without speaking of evaluation, since labeling something as quality again requires making a measurement, comparing it with an ideal referent and making a judgment on the adequacy of the evaluated object or subject to the referent used" [62,63].

\section{Limitations and Future Research}

The present study has some limitations. First, the study was conducted in one of the private universities in Chile and only in the medical school, so it cannot be replicated in other schools due to the particularity of the profession.

As part of the results of this approximation work, a series of interesting topics were found, such as the limits, challenges, strengths and opportunities to start teaching medical students in the digital era. Likewise, there remains the invitation to investigate topics such as: learning styles, teaching styles, teacher training design, among others. Therefore, teacher education and training in this area is fundamental in the agenda of contemporary pedagogy, which should not confuse this type of education with distance education models.

Another important aspect of this research was to realize that within the context of student satisfaction, teacher and educational quality management, aspects such as the tool for the use of teaching and learning from online education with quality, digital resources and techniques, thematic content, didactic strategy were defined and each is a field of research to deepen the implementation of the 4.0 era in education with quality.

Furthermore within the understanding of the online educational field from this research, the need for a didactic model that introduces the teacher in the use of technological platforms for educational purposes with quality begins to be observed. With the fact that the aspects found can be divided into three stages, which would be: 
Technological stage: constituted by the tool and digital resources. Didactic stage: formed by the thematic contents and the didactic strategy for teaching the contents and, finally, a stage that would unite the two previous ones: it is the technical stage that we can understand as the stage that explains the operation. In other words, the technical stage, as observed in this research, is fundamental for the educational process to develop in a three-dimensional environment by understanding the aspects that compose it and applying them for educational purposes.

\section{Conclusions}

Advances in educational systems have influenced the dynamics of human society, including the way education is designed and implemented in complex scenarios. Currently, the tools used go hand in hand with information and communication technologies, which are used for various purposes to meet different needs. Given the objective of the present research which was to contribute to improve the quality of online learning currently offered by HEIs and the evaluation of students in the digital transformations that HEIs will continue to manage until the effects of COVID-19 are controlled.

In the present research we were able to demonstrate that quality management in learning processes and development throughout the academic life of medical students are fundamental requirements for them to remain balanced in the era of knowledge, which must always be at the forefront in all sectors of education, and even more so when faced with online learning.

The PLS-SEM estimation model used, and the subsequent Importance-Performance Map Analysis (IPMA), shows that educational processes must respond to a learning and learner-centered model, where the learner is the protagonist in the development of a knowledge management and quality process. In this sense, the student takes the leading role and is recognized as an important and participatory actor in the online teaching and learning processes, the new generation makes it possible for students to learn interactively, collaborate and share ideas with each other.

This has become an important component of educational technology in higher education worldwide, which has led to more rigorous processes for quality standards. This is the main reason why we set up a research prospective to acquire important data to answer future research gaps, which should focus on the ethical aspects of using these technologies for quality, educational and sustainable purposes. On the other hand, educational quality from a sustainable perspective in Latin American scenarios does not escape closely related concepts, being a platform for continuous improvement for the higher education system.

If we speak of quality, it is because implicitly or explicitly an evaluation has been carried out, and if it is evaluated, it is done with some criteria. In this sense, it is hardly congruent to speak of quality without speaking of evaluation, since labeling something as quality requires a measurement, comparing it with an ideal referent and issuing a judgment on the adequacy of the object or subject evaluated to the referent used.

Author Contributions: Conceptualization, Á.A.-D., E.C.V. and S.M.-P.; methodology, S.M.-P., Á.A.-D. and C.J.-B.; software, S.M.-P., C.J.-B., M.M.-M. and L.A.-G.; validation, Á.A.-D., C.J.-B. and S.M.-P.; formal analysis, S.M.-P.; investigation, C.J.-B. and Á.A.-D.; resources, C.J.-B.; data curation, S.M.-P., L.A.-G. and M.M.-M.; writing-original draft preparation, Á.A.-D., C.J.-B. and S.M.-P.; writingreview and editing, Á.A.-D., C.J.-B. and S.M.-P.; visualization, Á.A.-D. and E.C.V.; supervision, C.J.-B. and Á.A.-D.; project administration, C.J.-B.; funding acquisition, C.J.-B., Á.A.-D. and S.M.-P. All authors have read and agreed to the published version of the manuscript.

Funding: This research received no external funding.

Institutional Review Board Statement: Not applicable.

Informed Consent Statement: Not applicable.

Data Availability Statement: Data are available upon request from the authors.

Conflicts of Interest: The authors declare no conflict of interest. 


\section{References}

1. Tlili, A.; Zhang, J.; Papamitsiou, Z.; Manske, S.; Huang, R.; Kinshuk; Hoppe, H.U. Towards utilising emerging technologies to address the challenges of using Open Educational Resources: A vision of the future. Educ. Tech. Res. Dev. 2021, 69, 515-553. [CrossRef]

2. Martensen, A.; Grønholdt, L.; Eskildsen, J.K.; Kristensen, K. Measuring student oriented quality in higher education: Application of the ECSI methodology. Sinergie-Rapp. Ric. 2000, 9, 371-383.

3. Jung, H.J.; Ahn, J. La educación surcoreana bajo la globalización psicocultural. J. Soc. Psychol. Anthropol. 2021, 49, 3-10. [CrossRef]

4. Archer, L.; Hutchings, M.; Ross, A. Higher Education and Social Class. Issues of Exclusion and Inclusion; Routledge: Reino Unido, UK, 2003.

5. Müller, D.; Renes, S. Fairness views and political preferences: Evidence from a large and heterogeneous sample. Soc. Choice Welf. 2021, 56, 679-711. [CrossRef]

6. Brunner, J.J.; Uribe, D. Mercados Universitarios: El Nuevo Escenario de la Educación Superior; Ediciones Universidad Diego Portales: Santiago, Chile, 2007.

7. Tsiligiris, V.; Hill, C. A prospective model for aligning educational quality and student experience in international higher education. Stud. High. Educ. 2021, 46, 228-244. [CrossRef]

8. Buil, I.; Hernández, B.; Sese, F.; Urquizu, P. Los foros de discusión y sus beneficios en la docencia virtual: Recomendaciones para un uso eficiente. Innovar 2012, 22, 131-143.

9. González-Zamar, M.-D.; Abad-Segura, E.; López-Meneses, E.; Gómez-Galán, J. Managing ICT for Sustainable Education: Research Analysis in the Context of Higher Education. Sustainability 2020, 12, 8254. [CrossRef]

10. Nhan, T.T.; Nguyen, H.C. Quality challenges in transnational higher education under profit-driven motives: The Vietnamese experience. Issues Educ. Res. 2018, 28, 138-152.

11. Restaino, M.; Vitale, M.P.; Primerano, I. Analysing International Student Mobility Flows in Higher Education: A Comparative Study on European Countries. Soc. Indic. Res. 2020, 149, 947-965. [CrossRef]

12. Juarros, M.F. Configuraciones Emergentes en la Educación Superior Latinoamericana. Available online: https://dialnet.unirioja. es/servlet/articulo?codigo=1972909 (accessed on 1 September 2005).

13. Baathuli Nfila, R.; Darko-Ampem, K. Developments in academic library consortia from the 1960s through to 2000: A review of the literature. Libr. Manag. 2002, 23, 203-212. [CrossRef]

14. Espinoza, O.; González, L. Acceso a Instituciones de Educación Superior Públicas y Privadas: El Caso de Chile; Brunner, E.J.J., Peña, C., Eds.; El conflicto de las Universidades: Entre lo Público y lo Privado; Ediciones Universidad Diego Portales: Santiago, Chile, 2011.

15. Teixeira, P.; Rocha, V.; Biscaia, R.; Cardoso, M.F. Myths, beliefs and realities: Public-private competition and program diversification in higher education. J. Econ. Issues 2012, 46, 683-704. [CrossRef]

16. Reychav, I.; McHaney, R. The relationship between gender and mobile technology use in collaborative learning settings: An empirical investigation. Comput. Educ. 2017, 113, 61-74. [CrossRef]

17. Mâță, L.; Clipa, O.; Cojocariu, V.-M.; Robu, V.; Dobrescu, T.; Hervás-Gómez, C.; Stoica, I.V. Students' Attitude towards the Sustainable Use of Mobile Technologies in Higher Education. Sustainability 2021, 13, 5923. [CrossRef]

18. Barrientos Oradini, N.; Araya Castillo, L.; Duque, Á.A.; Yáñez Jara, V.; Gambra Acle, X.; Cornejo Orellana, C. Gratuidad de la Educación Superior en Chile. Arandu-UTIC. Revista Científica Internacional de la Universidad Tecnológica Intercontinental. 2020, Volume 7, pp. 163-188. Available online: http:/ / www.utic.edu.py/revista.ojs/index.php/revista/article/view/102 (accessed on 7 July 2021).

19. Acevedo-Duque, Á.; Argüello, A.; Pineda, B.; Turcios, P. Competencias del Docente en Educación Online en Tiempo de COVID-19. Available online: https:/ / dialnet.unirioja.es/servlet/articulo?codigo=7599941 (accessed on 9 September 2021).

20. Povorina, E.V.; Vasileva, L.A.; Ponyashova, A.S.; Volkov, D.V.; Kulyamina, O.S. Methodology for monitoring the quality of provided educational services in higher educational institutions. Laplage em Rev. 2021, 7, 190-197. [CrossRef]

21. Fishman, L.I.; Sosunova, L.A.; Noskov, S.V.; Agafonova, V.V.; Sivaks, A.N. Conceptualization of notions and formation of quality indicators of educational services. Helix 2018, 8, 3651-3660. [CrossRef]

22. Tavakoli, N.; Yadegarfar, G.; Bagherian, H.; Ghasri, F. Assessing the educational services quality of health information technology students. J. Educ. Health Promot. 2019, 8, 168. [CrossRef]

23. Chai, H. Un estudio empírico de la falla del servicio y la recuperación del servicio: Una perspectiva de la calidad del servicio educativo. Rev. Matemáticas Interdiscip. 2017, 20, 867-879. [CrossRef]

24. United Nations Educational, Scientific and Cultural Organzation. EFA Global Monitoring Report 2005; UNESCO: New York, NY, USA, 2005.

25. Laval, C. La Escuela no es Una Empresa; Paidós: Buenos Aires, Argentina, 2004.

26. Duhalde, M. Pedagogía Crítica y Formación Docente; Godotti, M., Gómez, M.V., Mafra, J., de Alentar, A.F., Eds.; En Publicación: Paulo Freire; Contribuciones para la Pedagogía; Consejo Latinoamericano de Ciencias Sociales (CLACSO): Buenos Aires, Argentina, 2008.

27. Sander, B. Gestión Educativa en América Latina: Construcción y Reconstrucción del Conocimiento; Editorial Troquel: Buenos Aires, Argentina, 1996.

28. Flecha García, J.R. Los Profesores Como Intelectuales: Hacia una Formación Integral de los Maestros del Siglo XXI; Revista Interuniversitaria de Formación Profesional: Barcelona, España, 1997; Volume 29, pp. 67-76. 
29. Flecha García, R. Pensamiento y Acción Crítica en la Sociedad de la Información; Piérola, E.J.G., Peña, J.G., Crítica, E.d., Eds.; Editorial Laboratorio Educativo: Caracas, Venezuela, 1997; pp. 29-40.

30. Ali, W.; Kaur, M. Mediating educational challenges amidst Covid-19 pandemic. Asia Pac. J. Contemp. Educ. Commun. Technol. 2020, 6, 40-57.

31. Alrasheedi, M.; Capretz, L.F.; Raza, A. A systematic review of the critical factors for success of mobile learning in higher education (university students' perspective). J. Educ. Comput. Res. 2015, 52, 257-276. [CrossRef]

32. Briggs, K.L.; Wohlstetter, P. Key Elements of a Successful School-Based Management Strategy. J. Sch. Eff. Sch. Improv. 2003, 4, 351-372. [CrossRef]

33. Ojasalo, J. Calidad de servicio a corto y largo plazo. Rev. Int. Cienc. Calid. Serv. 2019, 11, 620-638. [CrossRef]

34. Briceño, M.; Correa, S.; Valdés, M.; Hadweh, M. Modelo de gestión educativa para programas en modalidad virtual de aprendizaje. Rev. Cienc. Soc. 2020, 26, 286-298.

35. Paredes-Chacín, A.; Inciarte, A.; Walles- Peñaloza, D. Educación superior e investigación en Latinoamérica: Transición al uso de tecnologías digitales por Covid-19. Rev. Cienc. Soc. 2020, 26, 98-117.

36. Acevedo-Álvarez, R.; Fernández-Díaz, M.J. La percepción de los estudiantes universitarios en la medida de la comptencia docente: Validación de una escala. Rev. Educ. 2004, 28, 154-166. [CrossRef]

37. Ávila, J.G. El proceso de internacionalización de la educación superior latinoamericana. Rev. Estud. Educ. Int. 2007, 11, 400-409. [CrossRef]

38. Guzmán Valenzuela, C. Disrupting curricula and pedagogies in Latin American universities: Six criteria for decolonising the university. Teach. High. Educ. 2021, 1-19. [CrossRef]

39. Salazar-Gómez, E.; Tobón, S. Análisis documental del proceso de formación docente acorde con la Sociedad del conocimiento. Rev. ESPACIOS 2018, 39, 17-30.

40. Carabelli, P. Respuesta al brote de COVID-19: Tiempo de enseñanza virtual. InterCambios. Dilemas Transic. Educ. Super. 2020, 7 , 189-198. [CrossRef]

41. Martínez, D.; Gaetan, S.; Romero, J.; Saavedra, M.; Alvarado, P. Caracterización de la Práctica Docente Universitaria. Estudio de casos: Pregrado. Mater's Thesis, Universidad Javeriana, Cali, Colombia, 2005.

42. Zhang, Y.; Tsang, M. Gender gap in the national college entrance exam performance in china: A case study of a typical Chinese municipality. Asia Pac. Educ. Rev. 2015, 16, 27-36. [CrossRef]

43. Douglass, J.A. (Ed.) The New Flagship University: Changing the Paradigm from Global Ranking to National Relevancy; Springer: Berlin/Heidelberg, Germany, 2016.

44. Merma-Molina, G.; Gavilán-Martín, D.; Álvarez-Herrero, J.-F. Educación para el desarrollo sostenible: El impacto de los valores en la adicción a la telefonía móvil. Sostenibilidad 2021, 13, 1479. [CrossRef]

45. Grindrod, K.; Morris, K.; Killeen, R. Assessing Performance and Engagement on a Computer-Based Education Platform for Pharmacy Practice. Pharmacy 2020, 8, 26. [CrossRef] [PubMed]

46. Reyes, C. Medición de la calidad universitaria en Chile: La influencia de los rankings. Calid. Educ. 2016, 44, 158-196. [CrossRef]

47. Spencer, D.; Temple, T. Examining Students' Online Course Perceptions and Comparing Student Performance Outcomes in Online and Face-to-Face Classrooms. Online Learn. 2021, 25, 233-261. [CrossRef]

48. Müller, J.; Acevedo-Duque, Á.; Müller, S.; Kalia, P.; Mehmood, K. Predictive Sustainability Model Based on the Theory of Planned Behavior Incorporating Ecological Conscience and Moral Obligation. Sustainability 2021, 13, 4248. [CrossRef]

49. Hair, J.F.; Sarstedt, M.; Ringle, C.M.; Gudergan, S.P. Advanced Issues in Partial Least Squares Structural Equation Modeling (PLS-SEM); Sage: Thousand Oaks, CA, USA, 2018.

50. Ramírez-Castillo, N.A.; Müller-Pérez, J.; Acevedo-Duque, Á.; Müller-Pérez, S.; González-Díaz, R.R.; Suarez Campos, J.; OvallesToledo, L.V. Sustainable Moviegoer Intention to Attend Cinemas Based on the Theory of Planned Behavior. Sustainability 2021, 13, 8724. [CrossRef]

51. Hair, J.F.; Hult, G.T.M.; Ringle, C.M.; Sarstedt, M. Manual de Partial Least Squares Structural Equation Modeling (PLS-SEM), 2nd ed.; Sage: Thousand Oaks, CA, USA, 2017.

52. Betancourt-Odio, M.A.; Sartor-Harada, A.; Ulloa-Guerra, O.; Azevedo-Gomes, J. Self-Perceptions on Digital Competences for M-Learning and Education Sustainability: A Study with Teachers from Different Countries. Sustainability 2021, 13, 343. [CrossRef]

53. Esteve-Faubel, R.P.; Oller-Benitez, A.; Aparicio-Flores, M.P. Percepciones de los futuros profesores de Educación y Comunicación Audiovisual. Desafíos en la formación para una educación sostenible. Sostenibilidad 2020, 12, 10296. [CrossRef]

54. Albornoz, M.E. ¿Calidad educativa significa lo mimos para todos los actores escolares? Recuperado 2005. Available online: http:/ / mayeuticaeducativa.idoneos.com/index.php/347332 (accessed on 1 September 2021).

55. González-Zamar, M.-D.; Abad-Segura, E.; López-Meneses, E.; Gómez-Galán, J. Gestión de las TIC para la educación sostenible: Análisis de la investigación en el contexto de la educación superior. Sostenibilidad 2020, 12, 8254. [CrossRef]

56. Pulido Chaves, O. La Cuestión de la Calidad Educativa. Recuperado el 2 de Abril de 2010. 2009. Available online: http: //www.calidadeducativa.edusanluis.com.ar/2009/09/la-cuestion-de-la-calidad-dela.html (accessed on 5 September 2021).

57. Chau, P. Online higher education commodity. J. Comput. High Educ. 2010, 22, 177-191. [CrossRef]

58. Guo, F.; Hong, X.; Coates, H. Accelerated transformation: Designing global online higher education. High. Educ. Res. Dev. 2020, 39, 1322-1326. [CrossRef] 
59. Liu, Z.Y.; Chubarkova, E.; Kharakhordina, M. Online Technologies in STEM Education. Int. J. Emerg. Technol. Learn. 2020, 15, 20-32. Available online: https://www.learntechlib.org/p/217978/ (accessed on 30 August 2021). [CrossRef]

60. Lee, K. Rethinking the accessibility of online higher education: A historical review. Internet High. Educ. 2017, 33, 15-23. [CrossRef]

61. Rojas, M.M.; Moreno, G.A.; Rosero, C.A. Plataformas y herramientas educativas como parte del PLE del Docente. Caso asistente digital para planeación curricular ConTIC. INGE CUC 2016, 12, 99-106. [CrossRef]

62. Taleb, Z.; Sohrabi, Z. Aprendizaje en movimiento: El uso de la tecnología móvil para apoyar el aprendizaje de los estudiantes universitarios. Proc. Soc. Behav. Sci. 2012, 69, 1102-1109. [CrossRef]

63. Schleicher, A. The Impact of COVID-19 on Education: Insights from Education at a Glance 2020; OECD: Paris, France, 2020; Available online: https:/ / www.oecd.org/education/the-impact-of-covid-19-on-education-insights-education-at-a-glance-2020.pdf (accessed on 16 August 2020). 